\title{
Colorectal Cancer Screening: What Is the Population's Opinion?
}

\author{
Cristina Teixeira Cláudio Martins Daniel Trabulo Suzane Ribeiro \\ Cláudia Cardoso João Mangualde Ricardo Freire Élia Gamito \\ Ana Luisa Alves Isabelle Cremers Ana Paula Oliveira
}

Gastroenterology Department, Centro Hospitalar de Setúbal, Setúbal, Portugal

\section{Keywords}

Colorectal cancer · Screening · Survey · Colonoscopy

\section{Abstract}

Background: Colorectal cancer (CRC) is the first cause of death by cancer in Portugal and mortality has been increasing in the last 30 years. Materials and Methods: During a raising awareness campaign performed by our Gastroenterology Department, in Setúbal, Portugal, an anonymous written questionnaire was developed and presented in order to evaluate the population's knowledge and attitude regarding $C R C$ screening. Results: The following results were reported: 140 persons; mean age 54.6 years; $61.4 \%$ women; $22.1 \%$ had a family history of colorectal cancer. The main risk factors mentioned by the respondents were family history of CRC, previous history of intestinal polyps, and intestinal infection. Screening was considered useful by all respondents. About $60 \%$ of the respondents had been counselled, at least, on one screening technique, mainly by their general practitioner: colonoscopy in 31, fecal occult blood test in 44, and flexible sigmoidoscopy in 9. Most of the respondents had had the appropriate screening test, according to their age and family history. Fourteen of the respondents had not undergone the recommended screen- ing. Their answers showed that this was due to fear of pain/ discovering a disease as well as embarrassment. Conclusion: Although the majority of the respondents were aware of the importance of CRC screening, results show that there are still several misconceptions about risk factors, fear, and reluctance concerning the screening techniques. Awareness actions are useful to clarify possible questions and inform the population in order to increase compliance with screening.

(C) 2017 Sociedade Portuguesa de Gastrenterologia Published by S. Karger AG, Basel

\section{Rastreio de cancro colorretal: qual a opinião da população?}

\section{Palavras Chave \\ Cancro colorretal · Rastreio · Inquérito · Colonoscopia}

\section{Resumo}

Introdução: O cancro colorretal (CCR) é a primeira causa de morte por cancro em Portugal, com uma mortalidade que tem aumentado nos últimos 30 anos. Materiais e Mé-

\section{KARGER}

E-Mail karger@karger.com www.karger.com/pjg
(C) 2017 Sociedade Portuguesa de Gastrenterologia Published by S. Karger AG, Basel Karcer Open access

This article is licensed under the Creative Commons AttributionNonCommercial-NoDerivatives 4.0 International License (CC BYNC-ND) (http://www.karger.com/Services/OpenAccessLicense) Usage and distribution for commercial purposes as well as any distribution of modified material requires written permission.
Dr. Cristina Teixeira

Gastroenterology Department, Centro Hospitalar de Setúbal

Rua Camilo Castelo Branco

PT-2910-446 Setúbal (Portugal)

E-Mail ac.corda.teixeira@gmail.com 
todos: Durante uma acção de sensibilização levada a cabo por profissionais de saúde do Serviço de Gastrenterologia, em Setúbal, Portugal, foi realizado um inquérito escrito, anónimo, no sentido de avaliar os conhecimentos e atitudes da população face ao CCR. Resultados: 140 indivíduos; idade média 54.6 anos; $61.4 \%$ mulheres; $22.1 \%$ tinham pelo menos 1 familiar com CCR. Os factores de risco para CCR mais referidos foram a presença de pólipos e a história familiar. A infecção intestinal foi considerada como um factor de risco para CCR por $74 \%$ dos inquiridos, sendo que o rastreio foi considerado útil por todos. Tinha sido recomendado pelo menos um exame de rastreio a cerca de $60 \%$ dos participantes, a maioria por indicação do médico assistente de medicina geral e familiar: colonoscopia total em 31, pesquisa de sangue oculto nas fezes em 44 e rectossigmoidoscopia em 9 . Atendendo à idade e história familiar, a maioria efectuou um rastreio apropriado. Catorze pessoas não efectuaram o rastreio aconselhado; os motivos mais apontados foram o medo da dor/descobrir uma doença e vergonha. Conclusão: Embora a maioria dos inquiridos estivesse alerta para a importância do rastreio do CCR, persistem muitas ideias erradas em relação a factores de risco, receios e reticências quanto à realização dos exames de rastreio. Acções de sensibilização são úteis para clarificar dúvidas e informar a população no sentido de aumentar a adesão ao rastreio.

- 2017 Sociedade Portuguesa de Gastrenterologia. Publicado por S. Karger AG, Basel

\section{Introduction}

Colorectal cancer (CRC) is the third most common cancer worldwide and the 2nd most common cancer in Europe. In 2012, it was accountable for 214,866 deaths in Europe, being the 2nd most common cause of cancerrelated deaths [1]. In Portugal, CRC mortality has been increasing since the 1980s [2].

The increase in CRC cases in the last 30 years is attributed to environmental factors, especially changes in lifestyle [2] (low physical activity, poor diet, obesity, smoking), and aging of the population [3]. CRC screening has been adopted in many Western countries (opportunistic or population-based). Effective screening allows to reduce CRC incidence by detecting and removing precancerous polyps and to decrease mortality by identifying malignancies at earlier stages [4].

Multiple screening options are available such as direct tests that primarily detect premalignant or malignant lesions (flexible sigmoidoscopy [FS], colonoscopy) and stool-based tests such as the fecal occult blood test (FOBT). In Portugal, in the last few years, all FOBTs used immunochemical tests.

In Portugal, the National Plan for Prevention and Control of Oncologic Diseases 2001-2005 recommended that individuals without familial risk and with ages between 50 and 74 years perform FOBT every 1-2 years, followed by a colonoscopy if the test is positive [5]. The Portuguese Society of Digestive Endoscopy also accepts other screening methods for this population such as FS every 5 years or a full colonoscopy every 10 years. Recommendations vary for those who have a family history of CRC, had a prior history of CRC or its precursors, and for individuals with inflammatory bowel disease.

Compliance superior to $50 \%$ of the population is usually required to determine screening efficiency [6]. A survey in Portugal revealed that, despite lacking knowledge regarding screening importance and therefore a reduced screening level, the population was receptive to screening [7].

In fact, other studies have shown that even if in the general population the concern about CRC is low, the majority is interested in attending screening when recommended [8].

Several other studies have assessed the preferences and opinions of the population regarding CRC screening. The population remains concerned regarding several aspects of colonoscopy namely invasiveness of the test, time consumption, fear of pain, and bowel preparation, which can affect adhesion to screening [9]. However, other studies evaluating colonoscopy in CRC screening showed increased compliance as it may obviate the need for repeat testing for up to 10 years [10].

This study aimed to assess the knowledge and opinion of the general population regarding CRC screening, and understand the concerns regarding different screening techniques. Moreover, it also attempted to assess if the participants in the study were being recommended the appropriate screening according to age and family history of CRC as well as the motives for not following their doctor's recommendation for screening.

Understanding the population's preferences and concerns regarding the CRC screening avoidance is essential to improve compliance.

\section{Materials and Methods}

A 3-day awareness campaign was performed in Setúbal, Portugal, in a big shopping center, regarding the importance of CRC screening. During the campaign, any doubts regarding CRC risk 
Table 1. Demographic data of respondents completing the questionnaire

\begin{tabular}{lccr}
\hline & Total & \multicolumn{1}{l}{ Male } & \multicolumn{1}{c}{ Female } \\
\hline Number, $n$ (\%) & $140(100)$ & $54(38.6)$ & $86(61.4)$ \\
Age (mean \pm SD), years & $54.7 \pm 13.3$ & $59.7 \pm 13.3$ & $51.6 \pm 12.5$ \\
Residence, $n(\%)$ & & & \\
$\quad$ Urban & $121(86.4)$ & $50(92.6)$ & $71(82.6)$ \\
$\quad$ Rural & $19(13.6)$ & $4(7.4)$ & $15(17.4)$ \\
Educational level, $n(\%)$ & & & \\
$\quad$ Primary school & $30(21.4)$ & $12(22.2)$ & $18(20.9)$ \\
$\quad$ Basic education & $26(18.6)$ & $14(25.9)$ & $12(13.9)$ \\
$\quad$ Secondary education & $41(29.3)$ & $15(27.8)$ & $26(30.3)$ \\
$\quad$ University degree & $43(30.7)$ & $13(24.1)$ & $30(34.9)$ \\
Family history of CRC, $n(\%)$ & $31(22.1)$ & $10(18.5)$ & $21(24.4)$ \\
\hline
\end{tabular}

CRC, colorectal cancer. and screening where answered by health professionals (doctors and nurses of our Gastroenterology Department).

During that period, individuals who were at the site of the awareness campaign were approached by the health professionals and were given a written questionnaire, were asked to fill it in and then return it to the health professionals. The anonymous survey, with close-ended and open-ended questions, included demographic data, knowledge about CRC, attitudes towards CRC, including screening, opinions about screening, and sources of information. It also evaluated the degree of compliance and suitability of screening and concerns of the population. Questionnaires that were not fully completed were excluded.

Data were analyzed afterwards. Statistical analysis was conducted with SPSS 21. Quantitative variables are reported as a mean and standard deviation or median, minimum and maximum. Categorical variables are reported as count and percentage in each category. The $\chi^{2}$ test was used for comparison of categorical variables and the Student $t$ test for comparison of continuous variables. A $p$ value of $\leq 0.05$ was considered statistically significant.

\section{Results}

\section{Demographics}

During the awareness campaign, we obtained 151 inquiries, and 11 incompletely filled in questionnaires were excluded. Baseline demographics of persons included in the study are reported in Table 1.

The mean age was $54.7 \pm 13.3$ years and $86(61.4 \%)$ were females. Most respondents $(86.4 \%)$ lived in urban centers. Regarding educational level, $21.4 \%$ had only completed the primary school, $18.6 \%$ had basic education, $29.3 \%$ secondary education, and $30.7 \%$ graduated from university.

When questioned about family history, $22.1 \%$ reported at least a 1st-degree relative diagnosed with CRC.
Table 2. Risk factors for CRC perceived by the respondents

\begin{tabular}{lc}
\hline Risk factors & $n(\%)$ \\
\hline Polyps & $114(81.4)$ \\
Family history of CRC & $105(75.0)$ \\
Intestinal infection & $104(74.4)$ \\
High fat diet & $94(67.1)$ \\
Smoking & $89(63.6)$ \\
Sedentary life & $68(48.6)$ \\
Diabetes & $51(36.4)$ \\
Exposure to radiation & $49(35.0)$ \\
Arterial hypertension & $35(25.0)$ \\
Iron deficiency & $26(18.6)$ \\
Contraception & $14(10.0)$ \\
Fruits and vegetables ingestion & $3(2.1)$ \\
\hline
\end{tabular}

CRC, colorectal cancer.
Regarding life habits, 55\% reported at least 3 days/ week of physical activity, $12.5 \%$ were smokers, and $35.7 \%$ were ex-smokers.

\section{General Knowledge about CRC}

The presence of intestinal polyps was pointed out as a risk factor by $81.4 \%$ of the respondents, family history by $75 \%$, and intestinal infection by $74.3 \%$. The entire list of potential risk factors for CRC assessed in this inquiry is presented in Table 2. Respondents with primary or basic education failed to identify a higher number of risk factors or selected more erroneous risk factors for CRC than individuals with secondary education or university studies $(4.05 \pm 1.44$ vs. $3.15 \pm 1.59, p=0.001)$. There was no difference regarding gender $(p=0.096)$. Respondents un-
64

GE Port J Gastroenterol 2018;25:62-67 DOI: $10.1159 / 000480705$
Teixeira et al. 
Table 3. Reasons appointed for not performing screening

\begin{tabular}{ll}
\hline Reasons & Total \\
\hline Colonoscopy & 9 \\
Fear of pain & 7 \\
Fear of discovering diseases & 3 \\
Shame & 2 \\
Lack of symptoms & 1 \\
Long waiting list & 1 \\
\hline Flexible sigmoidoscopy & 2 \\
Fear of pain & 1 \\
Fear of discovering diseases & 1 \\
Embarrassment & 1 \\
\hline Fecal occult blood test & 3 \\
Lack of time & 3 \\
\hline
\end{tabular}

der or above 50 years had similar knowledge about risk factors for CRC.

Most respondents (93.6\%) thought that CRC can be prevented and all of them (100\%) that screening is useful in preventing CRC. Overall, $97.8 \%$ of the surveyed considered that CRC can be treated if diagnosed at an early stage.

\section{Screening}

Sixty percent $(n=84)$ of the inquired persons had undergone at least 1 kind of screening. In 79\%, it had been recommended by their general practitioner, in $7.15 \%$ by a gastroenterologist, in $4.7 \%$ by the occupational health professionals, and in $2.4 \%$ by doctors from other specialties.

Regarding the type of screening, 44 participants (31\%) had been recommended FOBT, with 15 of those subsequently undergoing colonoscopy due to a positive FOBT.

FS had been recommended in 9 participants (6.4\%). Thereafter, 2 of them underwent colonoscopy for polypectomy. Colonoscopy had been recommended as the first screening technique in 31 respondents (22\%).

Fourteen persons revealed that they had not undergone the advised screening method. There were no differences regarding gender or level of education between individuals who chose not to perform the recommended screening technique ( 9 females; 9 respondents with secondary education or university degree).

The screening techniques which were prescribed but not performed were 9 colonoscopies, 2 FS, and 3 FOBT. The main reasons for avoiding screening were the anticipation of pain $(n=8)$ and fear of diagnosis $(n=4)$. Embarrassment was also pointed out by 3 respondents. The reasons for noncomplying with screening are listed by technique in Table 3.

Considering that people between 50 and 75 years should perform FOBT/colonoscopy and that in case of a family history of CRC they should undergo a colonoscopy, from the analysis of age and family history of CRC, $70 \%$ of the respondents had performed the appropriate screening. FOBT instead of colonoscopy had been performed as screening in 11 persons with a family history of CRC, 12 persons over the age of 50 had not undergone any kind of screening, and in 6 persons FOBT was performed despite being under 50 years of age.

\section{CRC Information Source}

The information sources regarding CRC reported by the respondents were media (71\%), their general practitioner (42\%), the Internet (8\%), and nurses (7\%). Twenty-two percent were not receiving information through any source. Twelve respondents had already participated in public awareness campaigns. A significant number of participants $(64 \%)$ considered they needed more information about CRC.

\section{Discussion}

Nowadays, CRC screening is widely available in Portugal, but there is still no population-based screening program. Most of the time, general practitioners discuss with their patients the risks and benefits of screening, recommend annual FOBT (immunochemical) and in case of a positive result, prescribe colonoscopy.

A high compliance rate is essential for an effective CRC program. The path to a successful screening program includes general information about CRC risks, different methods of screening, and easy accessibility.

Many studies have shown that there still is a significant percentage of individuals who lack knowledge regarding CRC, have never heard of screening [4], or believe that it is unnecessary [11].

In our survey, most of the participants considered family history of CRC and previous history of intestinal polyps as risk factors for CRC, but there were also some misconceptions such as previous intestinal infection considered by $74 \%$ of the participants as a risk factor for CRC. Regardless of their opinion about risk factors, most of them considered that CRC can be prevented and that screening is useful. 
There are still many doubts and concerns regarding the screening, such as personal beliefs that the test was "not needed," would be embarrassing or would cause pain, or anxiety over results $[4,11]$.

Those beliefs influence the individual choice regarding the screening method. A survey of healthy people approached the individual preference for a CRC screening technique regarding 4 domains: physical discomfort, inconvenience, embarrassment, and risk. FOBT was the preferred method of screening instead of colonoscopy, FS, and barium enema [12].

Other studies that evaluated the preferences of the population between FOBT and colonoscopy also showed that most participants prefer FOBT over colonoscopy [9, 13]. The main reasons were noninvasiveness and convenience of FOBT [13] and colonoscopy being considered a more time-consuming, disturbing, painful and annoying examination with more risks involved.

In accordance with these studies, our respondents had more concerns regarding endoscopic techniques, with the main reasons for not performing screening being fear of pain and diagnosis of disease, while for FOBT, the time needed for performing the test was the only reason appointed.

Studies have shown that doctors' recommendation seems to have an important role in compliance with CRC screening and in the way it is perceived by the population $[11,14]$.

In our population, the general practitioner was responsible for $79 \%$ of the recommendations for screening and was appointed as a CRC information source by $42 \%$ of the respondents. The role of general practitioners is therefore fundamental in explaining and recommending an appropriate CRC screening.

However, there were still $20.7 \%$ of respondents that were either not choosing the appropriate screening (by having no screening despite being recommended for age or not having colonoscopy recommended despite a family history of CRC) or were administered FOBT despite being under the recommended age for screening start.

This study has some limitations. Firstly, the segment of the population surveyed is mostly urban, with $30 \%$ having a university degree, and with $20 \%$ of the respondents reporting a family history of CRC, which may be a factor for a higher level of awareness and compliance with screening. Secondly, our survey contemplated a small sample size and the data is based only on self-report, and may therefore be biased.

\section{Conclusions}

Screening is fundamental for decreasing CRC deaths. There is still a lack of knowledge concerning CRC risk factors and people still express some misconceptions and fears regarding screening. It is of major importance to have informed general practitioners who can demystify fears and reinforce the need of screening to the population. To increase compliance, it is also necessary to continue improving the accessibility to several techniques of screening.

\section{Statement of Ethics}

This study did not require informed consent nor review/approval by the appropriate ethics committee.

\section{Disclosure Statement}

The authors have no conflicts of interest to declare.
1 Ferlay J, Soerjomataram I, Ervik M, Dikshit R, Eser S, Mathers C, Rebelo M, Parkin DM, Forman D, Bray F: GLOBOCAN 2012 v1.0: Cancer Incidence and Mortality Worldwide: IARC CancerBase No. 11. Lyon, International Agency for Research on Cancer. 2013. http://globocan.iarc.fr (accessed January 20, 2017).

2 Pinto CG, Paquete AT, Pissarra I: Colorectal cancer in Portugal. Eur J Heal Econ 2010;10: 65-73.
3 Tsoi K, Hirai H, Chan F, Griffiths S, Sung JYY: Predicted increases in incidence of colorectal cancer in developed and developing regions, in association with ageing populations. Clin Gastroenterol Hepatol 2017;15:892-900.

4 Janz NK, Wren PA, Schottenfeld D, Guire KE: Colorectal cancer screening attitudes and behavior: a population-based study. Prev Med 2003;37:627-634.

5 Plano Oncológico Nacional 2001-2005. DR Ia Série-B No 199.5233-300.
6 Pinto A: Rastreio do carcinoma do cólon e reto: eficácia e adesão. GE J Port Gastrenterol 2012;19:113-114.

7 Forno SEA, Castro Poças F, Matos ME: O cancro colorretal e o rastreio: conhecimentos e atitudes dos portuenses. GE J Port Gastrenterol 2012;19:118-125.

8 Wardle J, Sutton S, Williamson S, Taylor T, McCaffery K, Cuzick J, Hart A, Atkin W: Psychosocial influences on older adults' interest in participating in bowel cancer screening. Prev Med 2000;31:323-334. 
9 Almog R, Ezra G, Lavi I, Rennert G, Hagoel L: The public prefers fecal occult blood test over colonoscopy for colorectal cancer screening. Eur J Cancer Prev 2008;17:430-437.

10 Schoen RE, Weissfeld JL, Trauth JM, Ling BS, Hayran M: A population-based, community estimate of total colon examination: the impact on compliance with screening for colorectal cancer. Am J Gastroenterol 2002; $97: 446-451$
11 Weitzman ER, Zapka J, Estabrook B, Goins $\mathrm{KV}$ : Risk and reluctance: understanding impediments to colorectal cancer screening. Prev Med 2001;32:502-513.

12 Nelson RL, Schwartz A: A survey of individual preference for colorectal cancer screening technique. BMC Cancer 2004;4:76.
13 Wolf RL, Basch CE, Brouse CH, Shmukler C, Shea S: Patient preferences and adherence to colorectal cancer screening in an urban population. Am J Public Health 2006;96:809-811.

14 Gilbert A, Kanarek N: Colorectal cancer screening: physician recommendation is influential advice to Marylanders. Prev Med 2005;41:367-379. 